\title{
ANALYSIS OF FACTORS AND DEVELOPMENT OF METHODS FOR MANAGING THE ENVIRONMENTAL AND CIVIL SAFETY OF TRANSBOUNDARY TRANSPORTATION OF OIL AND OIL PRODUCTS THROUGH PIPELINES
}

\author{
Vladyslav Shuryhin ${ }^{1}$, Yulia Rak ${ }^{2}$, Vasyl Karabyn ${ }^{3}$ \\ ${ }^{1}$ Department of Environmental Safety, Lviv State University of Life Safety, Lviv, Ukraine \\ vlad_shurygin@ukr.net \\ ORCID: http://orcid.org/0000-0003-0324-4433 \\ ${ }^{2}$ Department of Environmental Safety, Lviv State University of Life Safety, Lviv, Ukraine \\ juliarak2100@gmail.com \\ ORCID: http://orcid.org/0000-0002-8642-3818 \\ ${ }^{3}$ Department of Civil Protection and Computer Modeling Ecology-Geophysical Processes, Lviv State University of Life Safety, Lviv, Ukraine \\ vasyl.karabyn@gmail.com \\ ORCID: http://orcid.org/0000-0002-8337-5355
}

ARTICLE INFO

Article history:

Received date 09.09.2020

Accepted date 15.10.2020

Published date 30.10 .2020

Section:

Waste Management and Disposal

D O I

$10.21303 / 2313-8416.2020 .001484$

KEYW ORDS

environmental safety

civil protection

emergency

oil transportation by pipelines

\section{ABSTRACT}

Transportation of oil and oil products through main pipelines is accompanied by the outpouring of these components into the environment, which creates risks of reducing the level of environmental safety and emergencies.

The object of research is the factors and methods of environmental and civil safety management of cross-border transportation of oil and oil products through pipelines.

Investigated problem is the analysis of environmental and civil safety management factors for cross-border transportation of oil and oil products through pipelines has been carried out and new technical and organizational solutions have been proposed to improve the level of management. The environmental safety of oil and gas facilities is defined as the state of environmentally safe functioning of oil and gas facilities and the absence of harmful environmental impact on these facilities. On the basis of the analysis of emergency situations on the linear part of the main oil pipelines, five main reasons leading to depressurization have been identified and ranked. The oil pipeline emergency is presented in a mathematical form. The analysis of depressurization of main oil pipelines in the world and in the Lviv region is carried out. The international normative legal acts regulating the management aspects of environmental and civil safety of cross-border transportation of oil and oil products are analyzed.

Innovative products - in case of water pollution as a result of a catastrophic inflow of oil products, it is proposed to use a patented installation for modeling the process of pollution of running water and a method of physical modeling of the process of spreading pollution as a result of a single discharge of oil products into the river. In the case of soil contamination with oil products, it was proposed to use a patented installation for modeling the process of filtration of contaminated solutions through the soil or bottom sediments. The advantages of the proposed new technical solutions based on known analogues are shown.

The area of practical use of the research results is the subdivisions of the Ministry of Environmental Protection and Natural Resources of Ukraine, the State Service of Ukraine for Emergency Situations, NJSC Naftogaz of Ukraine, higher educational institutions, research institutes of oil and gas ecological profile.

(C) The Author(s) 2020. This is an open access article under the CC BY license http://creativecommons.org/licenses/by/4.0).

\section{Introduction}

Transportation of oil and oil products through trunk pipelines is a complex organizational and technical process. Depressurization of oil pipelines causes pollution of environmental components, reduces the level of environmental safety and creates risks of emergencies. Improving the management of this process, including by introducing new technical solutions and ways facilitates the level of environmental and civil safety. 


\section{1. The object of research}

The object of research is the factors and methods of environmental and civil safety management of cross-border transportation of oil and oil products through pipelines.

\section{2. Problem description}

The development of the oil and gas industry is impossible without the development of pipeline transport infrastructure. In such areas, the anthropogenic load is much higher and is comparable to agricultural or residential areas.

According to statistics, Ukraine annually consumes up to 10 million tons of oil and oil products, 40 thousand tons of which are officially recorded losses as a result of the outpourings [1]. Such outpourings are sources of soil, groundwater and surface water pollution $[2,3]$. In case of contamination of territories near drinking water intakes, conditions for an emergency are created [4]. Therefore, the study of factors that lead to a decrease in the level of environmental and civil safety of transportation of oil and oil products through pipelines and the development of methods for managing these factors is an urgent task. The urgency of this task is significantly increasing in border areas, where an oil spill may subject the country to tough international sanctions.

\section{3. Suggested solution to the problem}

The oil and gas industry of Ukraine is represented by 6 oil refineries with a total primary processing capacity of 51-54 million tons of oil per year [5]. The system of main oil pipelines of Ukraine includes $4767 \mathrm{~km}$ of oil pipelines (in single-line terms) with a diameter of up to $1220 \mathrm{~mm}$ inclusive [6].

In order to increase the level of environmental and civil safety at the enterprises of NJSC "Naftogaz of Ukraine", a management policy has been developed. The elements of such management are emergency response units and services, voluntary fire brigades, persons responsible for the fire condition, regulations and instructions, conducting briefings and testing knowledge on fire and technological safety. The safety of work and emergency response at drilling, production, transportation, storage and processing facilities for oil and gas is ensured by emergency recovery and repair teams, a site, line maintenance services, and other emergency response units that are part of the structural units of enterprises. To prevent and eliminate emergencies, in 2018, helicopters overflew the pipeline route, bypassed pipeline sections by services, performed scheduled preventive and preventive maintenance, and reviewed hazardous areas [5]. All these measures significantly increase the level of environmental safety and civil security, however, the risks of emergencies of environmental genesis in such territories are still significant.

The aim of research is to analyze the factors of environmental and civil safety of cross-border transportation of oil and oil products through pipelines.

\section{Materials and methods of research}

To achieve the aim of research, the appropriate general scientific and special methods of scientific knowledge based on the principles of an objective, comprehensive and complex analysis of natural and technical processes and phenomena were used. The dialectical method made it possible to comprehensively and volumetrically study the formation of environmental and civil safety management factors for cross-border transportation of oil and oil products through oil pipelines, as well as to determine the objective causes of problems in the process of organizing the control system. The general scientific method of analysis made it possible to identify the causes of depressurization of oil pipelines, and the mathematical method of vector analysis - to mathematically describe an emergency situation on oil pipelines that occurs at a certain point in time. Methods of physical modeling and setting up experiments were used in the development of installations and a method of physical modeling. Generalization and induction methods are applied in the process of formulating conclusions.

\section{Research results}

Environmental safety of oil and gas facilities can be defined as the state of environmentally safe operation of oil and gas facilities and the absence of harmful environmental influ- 
ences on these facilities. In areas with a high concentration of oil and gas facilities, environmental safety issues are closely interconnected with civil protection issues, since large-scale outpourings of oil and oil products lead to emergencies.

Having analyzed emergency situations on the linear part of the main oil pipelines, it is possible to identify and rank five main reasons leading to depressurization (Fig. 1).

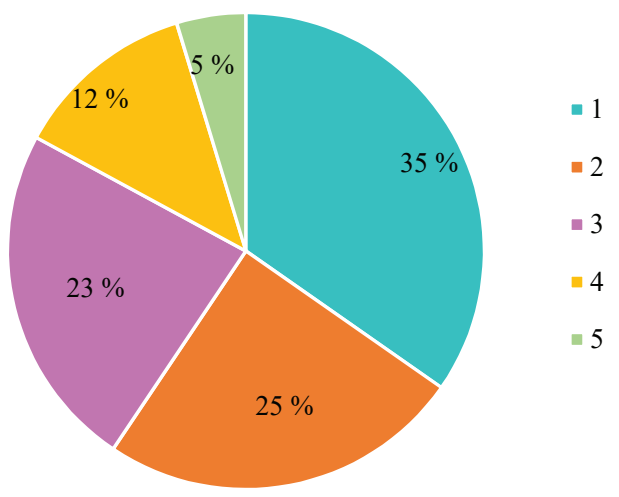

Fig. 1. Scheme of the main reasons for depressurization of main oil pipelines:

1 - external physical (force) actions on pipelines, including criminal tie-ins, which led to the origins $-34.7 \% ; 2$ - violation of the norms and rules of work during construction and repair, deviations from design solutions $-24.7 \% ; 3$ - corrosion damage to pipes, shutoff and control valves $-23.5 \% ; 4$ - violation of technical conditions in the manufacture of pipes and equipment $-12.4 \% ; 5$ - erroneous actions of the operating and maintenance personnel $-4.7 \%$ (processed according to [7])

Proceeding from this and modifying the vector, an emergency situation on oil pipelines was proposed in [8], which occurs at a certain moment in time $E(t)$, can be represented in a tuple of the form:

$$
<O(t), F(t), M(t), L(t)>,
$$

where $O(t)$ - the vector of state variables of the object at which the emergency occurred; $F(t)$ - vector of external destabilizing factors; $M(t)$ - the vector of control impacts aimed at reducing the scale of emergency situations; $L(t)$ - plan of emergency liquidation (localization), moreover:

$$
F(t)=\left(\begin{array}{l}
0.347 x_{1}(t) \\
0.247 x_{2}(t) \\
0.235 x_{3}(t) \\
0.124 x_{4}(t) \\
0.047 x_{5}(t)
\end{array}\right)
$$

where $x_{1}$ - external physical (force) actions on pipelines, including criminal tie-ins that led to the origins, $x_{2}$ - violation of the rules and regulations for work during construction and repair, deviations from design solutions, $x_{3}$ - corrosion damage to pipes, shut-off and control valves, $x_{4}$ - violation of technical conditions in the manufacture of pipes and equipment, $x_{5}$ - erroneous actions of operating and maintenance personnel.

Losses of oil and oil products occur at all stages of oil usage. The most dangerous threats to the environment are associated with emergency oil outflows that occur during the operation of oil pipelines and are accompanied by the ingress of spilled oil into water bodies.

According to the Lviv State Inspection for 2016-2019, on the territory of the Lviv region there were 6 emergency situations caused by illegal tie-ins into pipeline transport. As a result of such incisions, $7502 \mathrm{~m}^{2}$ of land and surface waters of the Yablunivka and Struga rivers were polluted. 
In world history, there are numerous examples of emergencies caused by the leakage of oil or oil products. According to [7], December 5, 2014, on the Ashkelon-Eilat oil pipeline in southern Israel, as a result of unsuccessful repair work on a ruptured pipe, 21.9 thousand barrels of oil spilled into the Arava desert, which caused economic damage in the amount of 7.6 million USD, catastrophic pollution of environmental zones, hospitalization of more than 80 people (Fig. 2).

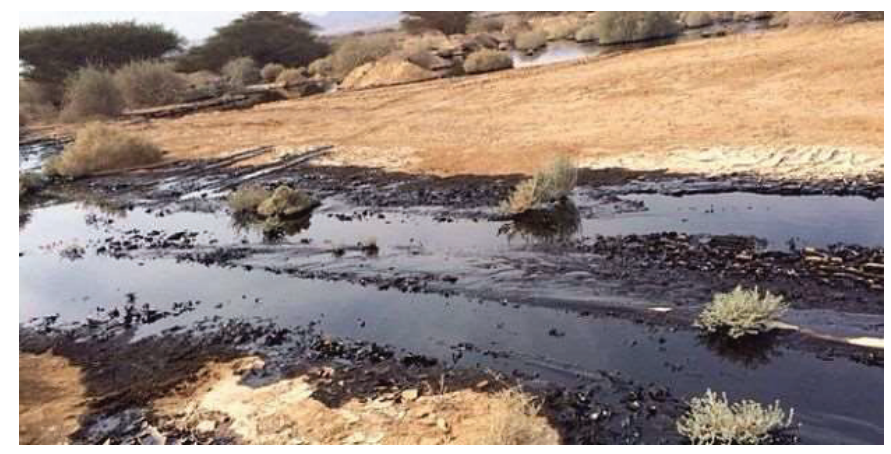

$a$

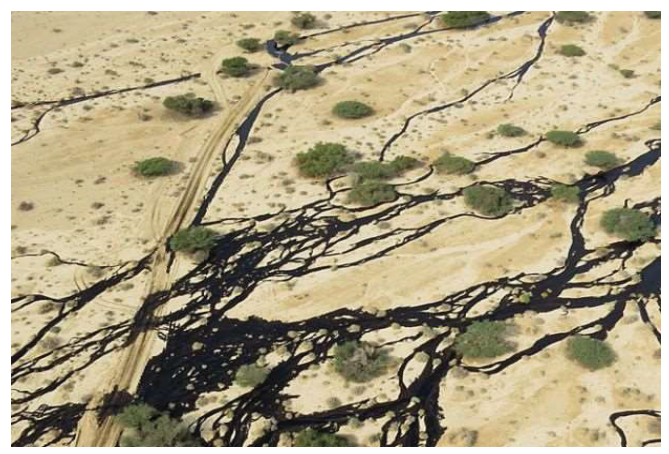

$b$

Fig. 2. Results of the accident at the Ashkelon-Eilat oil pipeline (photo by the Israeli Ministry of Ecology): $a$-view from a height of $1.5 \mathrm{~m} ; b$-view from a height of $600 \mathrm{~m}$

Technical solutions and measures have been developed to improve the level of environmental and civil safety management of cross-border transportation of oil and oil products through pipelines.

In case of water pollution as a result of a catastrophic inflow of oil products, an installation has been developed for modeling the process of pollution of running water [9] and a method for physical modeling of the process of spreading pollution as a result of a single discharge of oil products into the river [10].

In contrast to the known analogous installations for modeling, the proposed installation makes it possible to simulate the propagation of contamination in two-phase system water bottom sediments and to control the speed of water movement, which increases the reliability of the results (Fig. 3). Taken together, the patented installation and method make it possible to quickly predict the dynamics of a natural-man-made system that has undergone man-made impact, including as a result of depressurization of the oil pipeline.

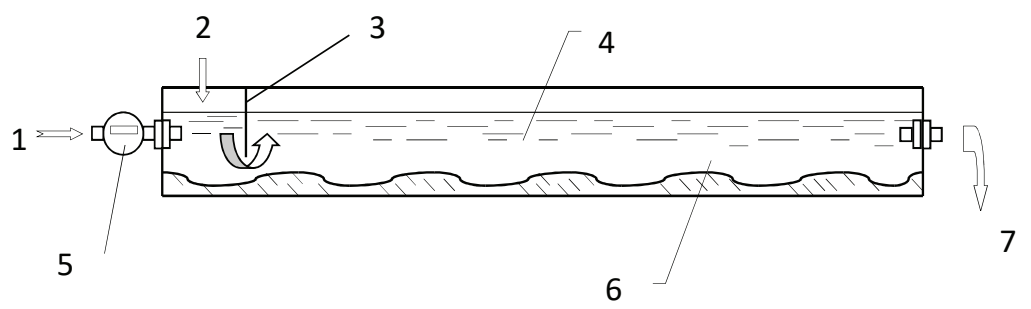

Fig. 3. Longitudinal section of the installation, physically simulates the process of river pollution by emergency discharge of pollutants:

1 - water supply hole, 2 - section for introducing pollutant, 3 - partition, 4 - water flow with pollutant, 5 - water meter, 6 - bottom sediments, 7 - water outlet

In case of soil contamination, let's propose to use an installation for modeling the process of filtration of contaminated solutions through the soil or bottom sediments [11]. The installation makes it possible to physically simulate the penetration of pollutants through the soil (Fig. 4). 


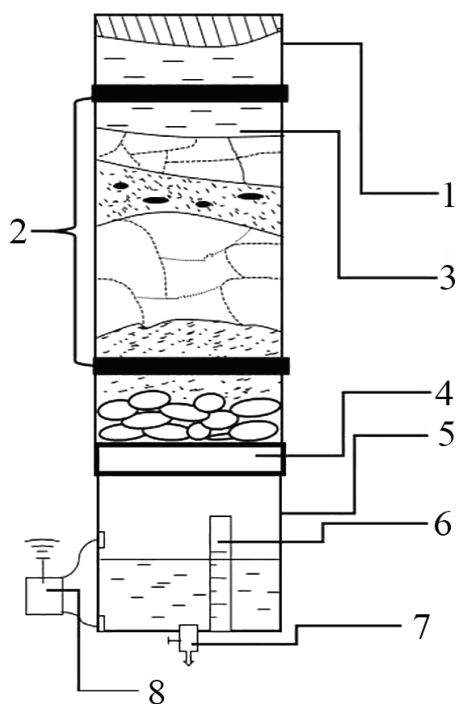

Fig. 4. Cross-section of an installation that simulates the process of soil pollution by emergency discharge of pollutants: 1 - container with chemically inert material, 2 - fastening system, 3 - first compartment, 4 - filter system, 5 - second compartment, 6 - filling level scale, 7 - tap for collecting and draining water, 8 - water level sensor

\section{Discussion}

At the present stage, the problems of environmental and civil security go far beyond national borders and have a transboundary, regional or even global character. The world community is trying to solve such problems by means of instruments for the adoption and implementation of international legal acts. International treaties are the main source of international law. In Ukraine, they are part of national legislation and are applied in the manner prescribed for the norms of national legislation [12]. The authors analyzed the international normative legal acts that regulate aspects of environmental and civil security of cross-border transportation of oil and oil products. The main ones are:

- international Convention on Intervention on the High Seas in Cases of Oil Pollution Accidents;

- convention for the Protection of the Black Sea against Pollution. Protocol on Cooperation in Combating Pollution of the Black Sea Marine Environment by Oil and Other Harmful Substances in Emergency Situations;

- international Convention on Civil Liability for Oil Pollution Damage.

International conventions and protocols are analyzed that make a positive contribution to improving environmental and civil safety in water bodies, but none of these documents contain mechanisms to compensate for the harm that can occur as a result of industrial accidents on an international scale.

Since September 1, 2017, the Association Agreement between Ukraine and the EU is in effect. Cooperation in the field of environmental protection is provided for in Articles 292-293 of Chapter 13 "Trade for Sustainable Development", Chapter 6 "Environment" of Section V "Economic and Industrial Cooperation" of the Association Agreement, and Annexes XXX and XXXI.

Cooperation aims at preserving, protecting, improving and reproducing the quality of the environment, protecting public health, prudent and rational use of natural resources and encouraging measures at the international level aimed at solving regional and global environmental problems. The parties pay special attention to issues of a transboundary nature [13].

According to the Transition Book 2019 "European and Euro-Atlantic integration" [14], the main tasks for Ukraine, among others, are the rational management of water resources.

The proposed solutions have a number of limitations. International treaties are capable of increasing the level of environmental and civil safety only if they are unconditionally fulfilled by all parties. The proposed installations of physical modeling, which are designed to reduce the time and increase the validity of management decisions in the event of an oil spill, do not provide for the possibility of changing pressure, which makes it impossible to use them for physical modeling in conditions of deep horizons. 
Prospects for further research lie in the area of developing a methodology for managing environmental and civil security of cross-border transportation of oil and oil products through pipelines.

\section{Conclusions}

1. Transportation of oil and oil products through main pipelines creates risks of lowering the level of environmental safety and emergencies.

2. Environmental safety of oil and gas facilities, this is the state of environmentally safe operation of oil and gas facilities and the absence of harmful environmental influences on these facilities.

3. An emergency situation on oil pipelines that occurs at a certain point in time $\mathrm{E}(\mathrm{t})$ can be represented in a tuple of the form $\langle O(t), F(t), M(t), L(t)\rangle$, where $O(t)$ - vector of state variables of the object on which the emergency occurred; $F(t)$ - vector of external destabilizing factors; $M(t)$ - vector of control impacts aimed at reducing the scale of emergency situations; $L(t)$ - plan of emergency liquidation (localization).

4. In the case of water pollution as a result of a catastrophic inflow of oil products, it is advisable to use an installation for modeling the process of pollution of running water and a method of physical modeling of the process of spreading pollution as a result of a single discharge of oil products into the river.

5. In the case of soil contamination, it is advisable to use an installation for modeling the process of filtration of contaminated solutions through the soil or bottom sediments.

\section{References}

[1] Derzhavna sluzhba statystyky Ukrainy (2016). Statystychnyi shchorichnyk Ukrainy. Kyiv. Available at: http://www.ukrstat.gov.ua/

[2] Sokolov, Y. V., Shevchenko R. I., Madani, M. M. (2020). Ecological assessment of the territorial complexes of Tatarbunars'kyi District of Odessa region. Visnyk of V. N. Karazin Kharkiv National University, Series «Geology. Geography. Ecology», 52, 216-235. doi: http://doi.org/10.26565/2410-7360-2020-52-16

[3] Malovanyy, M., Petrushka, K., Petrushka, I. (2019). Improvement of Adsorption-Ion-Exchange Processes for Waste and Mine Water Purification. Chemistry \& Chemical Technology, 13 (3), 372-376. doi: http://doi.org/10.23939/chcht13.03.372

[4] Karabyn, V., Popovych, V., Shainoha, I., Lazaruk, Ya. (2019). Long-term monitoring of oil contamination of profile-differentiated soils on the site of influence of oil-and-gas wells in the central part of the Boryslav-Pokuttya oil-and-gas bearing area. Petroleum and Coal, 61 (1), 81-89.

[5] Ministerstvo zakhystu dovkillia ta pryrodnykh resursiv Ukrainy (2019). Natsionalna dopovid pro stan navkolyshnoho pryrodnoho seredovyshcha v Ukraini u 2018 rotsi. Kyiv. Available at: https://mepr.gov.ua/timeline/Zviti.html

[6] Ukrainskyi naukovo-doslidnyi instytut tsyvilnoho zakhystu. (2019). Analitychnyi ohliad stanu tekhnohennoi ta pryrodnoi bezpeky v Ukraini za 2018 rik. Kyiv. Available at: https://www.dsns.gov.ua/ua/Analitichniy-oglyad-stanu-tehnogennoyi-taprirodnoyi-bezpeki-v--Ukrayini-za-2015-rik.html

[7] Zhdek, A. Ya. (2017). Otsinka vtrat nafty vid vytokiv pry transportuvanni i rozrobka zakhodiv yikh skorochennia. Ivano-Frankivsk, 165.

[8] Skrypnyk I. V. et. al. (1997). Ydentyfykatsyia y modelyrovanye upravliaiushchykh system. NAN Ukrainy. Kyiv: Naukova dumka.

[9] Karabyn V. V, Sysa L. V., Rak Yu. M. (2018). Pat. No. 123043 UA. Ustanovka dlia modeliuvannia protsesu zabrudnennia protichnoi richkovoi vody. MPK: G09B 23/12, G01N 33/24, G01N 33/18. No. u 2017 07530. declareted: 17.07.2017; published: 12.02.2018, Bul. No. 3.

[10] Karabyn, V. V., Sysa, L. V., Rak, Yu. M. (2017). Pat. No. 123350 UA. Sposib fizychnoho modeliuvannia protsesu poshyrennia zabrudnennia vnaslidok odnorazovoho skydu naftoproduktiv u richku. No. u201708610; declareted: 23.08.2017; published: 26.02.2018, Bul. No. 4. Available at: https://base.uipv.org/searchINV/search.php?action=viewdetails\&IdClaim=244532

[11] Shuryhin, V. I., Karabyn, V. V., Sysa, L. V. (2020). Pat. No. 143139 UA. Ustanovka dlia fizychnoho modeliuvannia protsesu filtratsiyi zabrudnenykh rozchyniv cherez tovshchu gruntu abo donnykh vidkladiv. No. u202001006; declareted: 17.02.2020; published: 10.07.2020, Bul. No. 13. Available at: https://base.uipv.org/searchINV/search.php?action=viewdetails\&IdClaim=269733

[12] Andrusevych, A., Andrusevych, N., Kozak, Z. (2009). Dovidnyk chynnykh mizhnarodnykh dohovoriv Ukrainy u sferi okhorony dovkillia. Lviv, 203.

[13] Uhoda pro asotsiatsiiu mizh Ukrainoiu, z odniiei storony, ta Yevropeiskym Soiuzom, Yevropeiskym spivtovarystvom z atomnoi enerhii i yikhnimy derzhavamy-chlenamy, z inshoi storony. Rozd. VI st. 361 (2014). Available at: https://zakon.rada.gov.ua/ laws/show/984_011\#Text

[14] Yevropeiska ta yevroatlantychna intehratsiia (2019). Kabinet Ministriv Ukrainy. Kyiv. Available at: https://www.kmu.gov.ua/ storage/app/sites/1/17-prezentation-2019/8.2019/transition-book-final-stisnuto.pdf 